Article

\title{
Utilization of Earth-to-Air Heat Exchanger to Pre-Cool/Heat Ventilation Air and Its Annual Energy Performance Evaluation: A Case Study
}

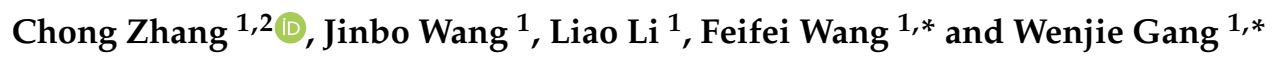 \\ 1 Department of Building Environment and Energy Engineering, Huazhong University of Science and \\ Technology, Wuhan 430074, China; chong0324.zhang@polyu.edu.hk (C.Z.); jbwang@hust.edu.cn (J.W.); \\ liliaow567@gmail.com (L.L.) \\ 2 Department of Building Services Engineering, The Hong Kong Polytechnic University, Hong Kong, China \\ * Correspondence: ffwang@hust.edu.cn (F.W.); gangwenjie@hust.edu.cn (W.G.)
}

Received: 7 September 2020; Accepted: 7 October 2020; Published: 10 October 2020

check for updates

\begin{abstract}
An earth-to-air heat exchanger (EAHE) system utilizes the low-grade thermal energy of underground soil to warm up and cool down the flowing air within an underground buried pipe. Integrating the EAHE system with building ventilation can reduce the energy demand for conditioning ventilation air. The main purposes of this paper are to estimate the year-round energy-saving potential of the EAHE-assisted building ventilation system and provide its design guidelines in a hot-summer and cold-winter climate. A steady-state heat transfer model was proposed to calculate the outlet air temperature of an EAHE and further identify its ability to preheat and precool ventilation air. Influences of depth, length, and diameter of a buried pipe on the year-round thermal performance of the EAHE system were evaluated. The results show that considering the compromise between thermal performance and construction costs of the EAHE system, a depth of $5 \mathrm{~m}$ and a length of $80 \mathrm{~m}$ are recommended. The EAHE system can provide a mean daily cooling and heating capacity of $19.6 \mathrm{kWh}$ and $19.3 \mathrm{kWh}$, respectively. Moreover, the utilization of the EAHE system can reduce by $16.0 \%$ and $50.1 \%$ the energy demand for cooling and heating ventilation air throughout the whole year.
\end{abstract}

Keywords: renewable energy; earth-to-air heat exchanger; sustainable building; building ventilation; building energy efficiency

\section{Introduction}

Nowadays, approximately $30 \%$ and $36 \%$ of the total energy use in China [1] and the world [2] is generated by the building sector during its whole life cycle, respectively. The building sector has been recognized as a significant portion for reducing global energy use and greenhouse gas emissions. In recent years, great efforts have been devoted toward the research and development of sustainable and high-performance buildings, in terms of improving building design guidelines [3], using advanced energy-efficient devices [4], enhancing the thermal performance of windows and walls [5,6], adopting a data-driven approach to achieve performance prediction and optimal control [7], taking advantages of renewable energy sources [8], improving indoor thermal comfort [9], integrating the thermal energy storage [10], etc. Building ventilation is essential for both residential and commercial buildings to satisfy the requirements of indoor air quality and thermal comfort [11]. However, the minimum ventilation requirement may lead to a large amount of energy consumption for conditioning ventilation air to the required conditions. Over the past several decades, better building design and emerging technologies have been constantly developed to reduce the energy demand of building ventilation.

Currently, air-to-air heat recovery exchangers are widely used to recover the latent and sensible heat of exhaust air to precondition ventilation air, which can significantly reduce the energy demand 
for conditioning ventilation air [12]. Advanced technologies such as membrane-based [13] or photovoltaic/thermal-collector-assisted [4] air-to-air heat recovery exchangers are proposed to further improve the energy performance of building ventilation systems. Moreover, it is estimated that about $20 \%$ to $40 \%$ of the total energy use for air conditioning results from the dehumidification process of ventilation air [14]. Compared with the conventional condensation dehumidification, the liquid desiccant-based air conditioning systems provide an alternative approach to remove the moisture from ventilation air with promising energy performance [15]. Meanwhile, there exists a passive approach by integrating the ventilation system with a building envelope to reduce the energy demand of building ventilation, such as dynamic insulation (also known as the breathing wall) [16] and the supply-air window [17]. These technologies allow the outdoor air to flow into indoor space through the pathway within building envelopes, and the outdoor air is preheated therein by recovering the heat loss of the building envelope in the heating season. In recent years, much research has emphasized the advantages of utilizing low-grade energy sources to reduce the energy demand for conditioning ventilation air. The evaporative cooling [18] and photovoltaic thermal (PVT) system [19] can be used to precool and preheat ventilation air in the cooling and heating seasons, respectively. Moreover, the earth-to-air heat exchanger (EAHE) can be treated as a low-grade heat source in winter and cold source in summer for preheating and precooling ventilation air, respectively [20].

The EAHE system is a kind of heat exchanger that can transfer heat between soil and ventilation airflow within underground buried pipes (as shown in Figure 1). The temperature of underground soil keeps approximately constant with a low fluctuation all year round when the depth reaches to a certain degree [21]. This makes the temperature of underground soil significantly higher or lower than the outdoor air temperature in winter or summer, respectively. In recent years, the energy-saving potential, optimal design, and heat transfer model of the EAHE system have been constantly investigated. Maoz et al. [22] and Lee et al. [23] pointed out that the diameter, depth, and length of buried pipes as well as airflow velocity within pipes show significant influence on the cooling and heating capacity of EAHE systems. Ascione et al. [24] recommended a depth of $3 \mathrm{~m}$ and a length of $50 \mathrm{~m}$ for the buried pipe of the EAHE system considering the compromise between construction costs and energy performance. Amanowicz and Wojtkowiak [25] provided a new design perspective of a multi-pipe EAHE system, which considers the influence of flow characteristics on the thermal performance. Minaei and Safikhani [26] developed a new transient analytical model to quickly and accurately predict the thermal performance of the EAHE. Gomat et al. [27] presented a simplified analytical model to estimate the impact of a vertical pipe on the thermal performance of the whole EAHE system. Moreover, the feasibility of applications of EAHE systems in different climate conditions has been fully explored. In the cooling-dominated climates, such as hot-arid or desert climate, the hot ambient air is sucked into the buried pipes and cooled down therein, and then the cool ventilation air is supplied into the indoor space. Al-Ajmi et al. [28] estimated that the maximum temperature difference between the outlet air of the EAHE system and ambient air can reach as high as $20.7^{\circ} \mathrm{C}$. Meanwhile, Belatrache et al. [29] pointed out that up to a $30 \%$ reduction of cooling energy demand can be achieved by adopting the EAHE system. Wei et al. [30] proposed a full-scale experimental platform with various configuration parameters to investigate the cooling capacity of the EAHE system in a hot and humid climate. For the heating-dominated climate, the EAHE can preheat the ventilation airflow within the buried pipes. Li et al. [31-33] conducted a series of experimental and numerical studies on the thermal performance of the EAHE system for a severe cold climate. The results show that the EAHE system can provide an average preheating potential of $14{ }^{\circ} \mathrm{C}$ for the heating condition, and the maximum COP is up to 16.3 . However, the study also pointed out that the underground soil temperature slightly decreases after a long-period operation of the heating mode, and seasonal alternate operation between the heating and cooling modes helps to maintain a stable underground soil temperature [31]. This means that the EAHE system has good applicability for the climate of hot-summer and cold-winter. Nowadays, some studies have been conducted to explore the application of the EAHE system in a hot-summer and cold-winter climate. Kumar et al. [34] investigated the cooling and heating capacity of the EAHE system for a 
non-air-conditioned room. The results show that the indoor air temperature can be maintained at $27.6^{\circ} \mathrm{C}$. Xamán et al. [35] developed a two-dimensional pseudo-transient model to analyze the daily thermal performance of the EAHE system on a typical summer and winter day. Liu et al. [36] proposed a novel vertical EAHE system and estimated the influence of some design parameters on its cooling and heating capacity. Although the above studies indicate that the EAHE system has promising thermal performance and good applicability, investigation on the EAHE system in a hot-summer and cold-winter climate is not enough, and especially in regard to the annual energy-saving potential and design guideline of the EAHE system for building ventilation.
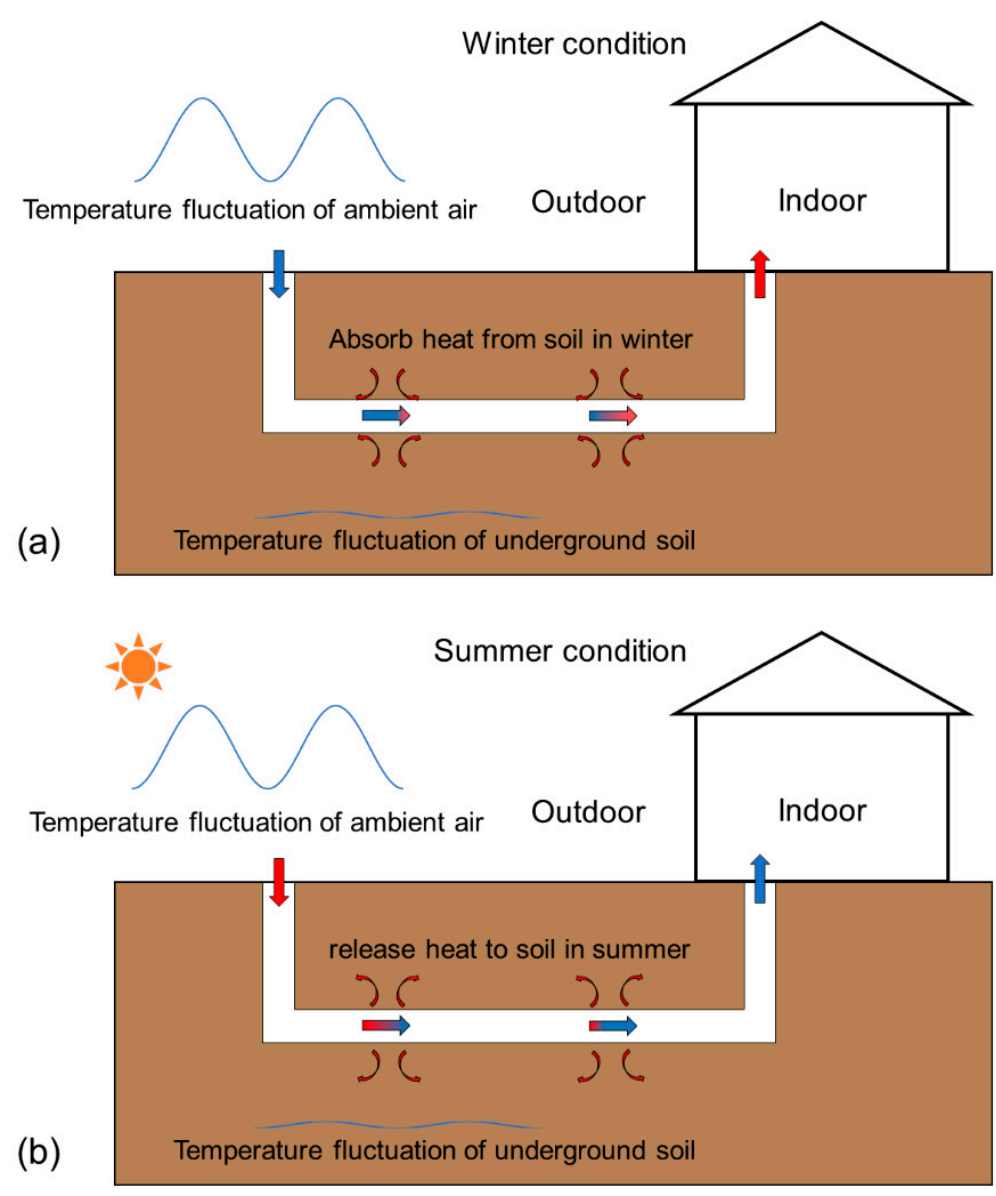

Figure 1. Schematic and principle of the earth-to-air heat exchanger (EAHE)-assisted building ventilation system: (a) winter condition; (b) summer condition.

The main objectives of the paper are to evaluate the annual energy-saving potential of the EAHE-assisted building ventilation system in a hot-summer and cold-winter climate and to provide its recommended design. In this study, a numerical model was developed to estimate the hourly precooling and preheating performance of the EAHE system in a hot-summer and cold-winter climate. The year-round energy-saving potential of the EAHE-assisted building ventilation system was investigated. The effects of some key design parameters such as depth, length, and diameter of the buried pipe on the precooling/preheating performance and energy-saving potential of the EAHE system in a hot-summer and cold-winter climate were quantitatively investigated. Moreover, its design guidelines in this climate condition and applications of the EAHE system for zero-energy buildings were also discussed. The contribution of this study is providing an approach to combine the EAHE system and building ventilation toward low-carbon-emission, energy-efficient, and sustainable buildings. The recommended design parameters, application guidelines, and comprehensive understanding of the EAHE-assisted building ventilation system in the hot-summer and cold-winter climate are also 
provided. Although this study only carried out a case study in a representative city of the hot-summer and cold-winter climate, it should be noted that the EAHE-assisted building ventilation system is globally applicable to both new buildings and energy-efficient retrofitting of the existing buildings.

The paper is organized as follows. The rationale of the EAHE-assisted building ventilation system is briefly introduced in Section 2. The methodology for investigating the thermal and energy performance of the EAHE is presented in Section 3. The simulation conditions of the case study are described in Section 4. In Section 5, the annual thermal performance and energy-saving potential of the EAHE-assisted building ventilation system are analyzed. The conclusions and perspectives on future work are summarized in Section 6.

\section{Description of the EAHE-Assisted Building Ventilation System}

The conceptual structure of the EAHE-assisted building ventilation system is illustrated in Figure 1. The underground buried pipe is the core component of the EAHE system. The ambient air is pumped into the pipe and exchanges heat with the adjacent underground soil therein, and eventually is supplied into indoor space for building ventilation. At a certain depth, the temperature of underground soil is approximately constant throughout the whole year. In summer, the hot ventilation air releases heat to the surrounding soil and is precooled before entering the indoor space. In winter, the cold ventilation air can absorb heat from the surrounding soil and be preheated. As a result, the energy demand for cooling and heating ventilation air can be significantly reduced by utilizing low-grade natural energy sources. Perhaps the EAHE system may be treated as a seasonal thermal energy storage system for the hot-summer and cold-winter climate.

\section{Methodology}

An analytical model of the underground soil temperature as a function of depth and time is developed in Section 3.1. This model can be used to calculate the hourly temperature evolution of underground soil at different depths. A steady-state heat transfer model was developed in Section 3.2 to calculate the outlet air temperature of the EAHE system. Moreover, some evaluation indexes such as precooling/preheating performance, daily cooling/heating capacity, and energy-saving potential are defined in Section 3.3.

\subsection{Mathematical Model of Underground Soil Temperature}

The underground soil temperature surrounding the buried pipe determines the precooling and preheating capacity of the EAHE. The underground soil is considered to be isotropic and homogeneous [37], and the one-dimensional heat conduction within the soil along the depth direction can be expressed as:

$$
\frac{\partial T_{s}}{\partial \tau}=\alpha_{s} \frac{\partial^{2} T_{s}}{\partial z^{2}}
$$

where $T_{S}$ is the temperature of underground soil along the depth direction, $\mathrm{K} ; \alpha_{s}$ is the thermal diffusivity of soil, $\mathrm{m}^{2} / \mathrm{h}$. The soil is assumed as a semi-infinite solid, and the analytical solution of Equation (1) can be expressed as a function of depth $(z)$ and time ( $t$ ) [28]. This analytical model for calculating the underground soil temperature was fully validated by comparing the measured data and calculated results in the work of Al-Ajmi et al. [38]. Such an analytical model is commonly used in the research field of the EAHE system [37-40].

$$
T_{S}(z, t)=T_{s, \text { mean }}-A_{s} \exp \left(-z \sqrt{\frac{\pi}{8760 \alpha_{s}}}\right) \cos \left(\frac{2 \pi}{8760}\left(t-t_{0}-\frac{z}{2} \sqrt{\frac{8760}{\pi \alpha_{s}}}\right)\right)
$$

where $T_{s, \text { mean }}$ is the mean annual temperature of the soil surface, $\mathrm{K} ; A_{s}$ is the amplitude of annual soil surface temperature, $K ; t_{0}$ means the time of minimum annual soil surface temperature. In this study, the temperature of the soil surface was assumed to be equal to that of ambient air. Such an assumption 
is commonly used in the relevant studies [37-40]. The values of the above parameters for case studies are defined in Section 4.

\subsection{Mathematical Model of the EAHE}

A steady-state heat transfer model of the EAHE system was developed to evaluate its precooling and preheating performance. Heat transfer processes within the EAHE contain three parts: convection between flowing air and the inside surface of the buried pipe, heat conduction within the pipe wall, and heat conduction within the soil surrounding the buried pipe. The heat transferred from the flowing air influences the temperature of the surrounding soil. However, the soil temperature is approximatively constant at a certain distance from the outside surface of the buried pipe [39]. In this study, the distance between the outer surface of the buried pipe and undisturbed soil surface, as shown in Figure 2, was assumed equal to the external radius of the buried pipe [28,39]. The temperature of the undisturbed soil surface was used as the boundary condition of the EAHE.

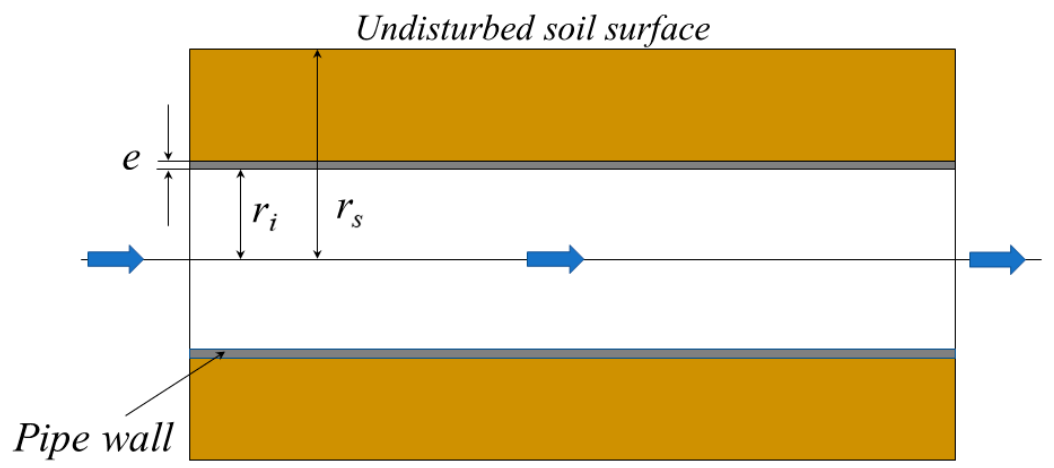

Figure 2. Vertical cross-section of the buried pipe.

The heat gain/loss of ventilation air within the buried pipe can be expressed as:

$$
d Q=m_{a} C_{a} \frac{d T_{a}}{d x} d x
$$

where $m_{a}$ is the mass flow rate of ventilation air, $\mathrm{kg} / \mathrm{h} ; C_{a}$ is the specific heat capacity of air at constant pressure, $\mathrm{kJ} /(\mathrm{kgK})$. The heat transferred between ventilation air and the surrounding soil can be defined as:

$$
d Q=\left(T_{s}-T_{a}\right) \frac{1}{R_{\text {total }}} d x
$$

where $T_{s}$ is the undisturbed soil temperature which can be calculated by Equation (2), K; $R_{\text {total }}$ is the total thermal resistance of the EAHE, $(\mathrm{mK}) / \mathrm{W}$. Based on energy balance, Equations (3) and (4) can be further expressed as:

$$
m_{a} C_{a} \frac{d T_{a}}{d x} d x=\left(T_{s}-T_{a}\right) \frac{1}{R_{\text {total }}} d x
$$

The solution of Equation (5) obtains Equation (6) [40] to calculate the outlet air temperature of the EAHE system. The accuracy and reliability of this model were validated by comparing the calculated results with the measured data in the studies of Derbel and Kanoun [39] and Bansel et al. [41]. In this study, Equation (6) was used to calculate the outlet air temperature of the EAHE system.

$$
T_{\text {outlet }}=T_{s}+\left(T_{a m b}-T_{s}\right) \exp \left(-\frac{L}{m_{a} C_{a} R_{\text {total }}}\right)
$$

where $L$ is the length of the buried pipe, $\mathrm{m} ; T_{a m b}$ is the ambient air temperature, $\mathrm{K}$. In this study, the total thermal resistance of the EAHE $\left(R_{\text {total }}\right)$ contained three parts: convective thermal resistance 
between the flowing air and pipe wall $\left(R_{\text {conv }}\right)$, conductive thermal resistance of the pipe wall $\left(R_{\text {pipe }}\right)$, and conductive thermal resistance between the outer surface of the buried pipe and undisturbed soil surface $\left(R_{\text {soil }}\right)$. The $R_{\text {total }}$ can be defined as:

$$
R_{\text {total }}=R_{\text {conv }}+R_{\text {pipe }}+R_{\text {soil }}
$$

The $R_{\text {conv }}, R_{\text {pipe, }}$ and $R_{\text {soil }}$ can be further expressed as:

$$
\begin{gathered}
R_{\text {conv }}=\frac{1}{2 \pi r_{i} h} \\
R_{\text {pipe }}=\frac{1}{2 \pi k_{p}} \ln \left(\frac{r_{i}+e}{r_{i}}\right) \\
R_{\text {soil }}=\frac{1}{2 \pi k_{s}} \ln \left(\frac{r_{s}}{r_{i}+e}\right)
\end{gathered}
$$

where $r_{i}$ is the inner radius of the pipe, $\mathrm{m}$; $e$ is the thickness of the pipe wall, $\mathrm{m} ; r_{s}$ is the radius of the undisturbed soil surface, $\mathrm{m} ; k_{p}$ and $k_{s}$ are the thermal conductivities of the pipe and surrounding soil, $\mathrm{W} /(\mathrm{mK}) ; h$ is the convective heat transfer coefficient between the pipe wall and adjacent air, which can be calculated by Equation (11), $\mathrm{W} /\left(\mathrm{m}^{2} \mathrm{~K}\right)$.

$$
h=\frac{N u k_{a}}{2 r_{i}}
$$

where $k_{a}$ is the thermal conductivity of air, $\mathrm{W} / \mathrm{mK}$. The Nusselt number of ventilation air within the buried pipe can be calculated by the following correlation proposed by Gnielinski [42]:

$$
N u= \begin{cases}3.66 & R e<2300 \\ \frac{(f / 8)(\operatorname{Re}-1000) P r}{1+12.7(f / 8)^{1 / 2}\left(\operatorname{Pr}^{2 / 3}-1\right)} & 2300 \leq \operatorname{Re}<5 \times 10^{6}\end{cases}
$$

where $f$ is the friction coefficient of the pipe, which can be expressed as:

$$
f=(1.82 \log (\operatorname{Re})-1.64)^{-2}
$$

\subsection{Evaluation Indexes}

In this study, the hourly precooling performance $\left(T_{\text {cool }}\right)$ and average daily cooling capacity $\left(Q_{\text {cool }}\right)$ of the EAHE system in the cooling season were calculated and defined as follows:

$$
\begin{gathered}
T_{\text {cool }}=T_{\text {outlet }}-T_{\text {amb }} \\
Q_{\text {cool }}=24 \times \frac{\sum_{t=1}^{H_{c}} m_{a} C_{a} T_{\text {cool }}(t)}{H_{\mathrm{c}}}
\end{gathered}
$$

where $N_{\mathrm{c}}$ is the cumulative hours for the cooling season. In the heating season, the preheating performance $\left(T_{\text {heat }}\right)$ and average daily cooling capacity $\left(Q_{\text {heat }}\right)$ were also calculated and expressed as follows:

$$
\begin{gathered}
T_{\text {heat }}=T_{\mathrm{amb}}-T_{\text {outlet }} \\
Q_{\text {heat }}=24 \times \frac{\sum_{t=1}^{N_{\mathrm{h}}} m_{a} C_{a} T_{\text {heat }}(t)}{N_{\mathrm{h}}}
\end{gathered}
$$


where $N_{\mathrm{h}}$ is the cumulative hours for the heating season. The energy demand for conditioning ventilation air without and with the EAHE system can be calculated by Equations (18) and (19) [43], respectively. In this study, the humidity ratio of ventilation air was controlled in both cooling and heating seasons.

$$
\begin{aligned}
Q_{\text {vent }} & =\sum_{\text {hours }}\left[m_{a} C_{a}\left(T_{\mathrm{amb}}-T_{i}\right)+m_{a} L_{a}\left(d_{\mathrm{amb}}-d_{i}\right)\right] \\
Q_{E A H E} & =\sum_{\text {hours }}\left[m_{a} C_{a}\left(T_{\text {outlet }}-T_{i}\right)+m_{a} L_{a}\left(d_{\text {outlet }}-d_{i}\right)\right]
\end{aligned}
$$

where $L_{a}$ is the latent heat vaporization of water, $\mathrm{kJ} / \mathrm{kg}$; hours is cumulative hours during the cooling or heating season; $T_{i}$ is the indoor temperature, $\mathrm{K} ; d_{i}, d_{\mathrm{amb}}$, and $d_{\text {outlet }}$ are the humidity ratios of the indoor environment, ambient air, and outlet air of the EAHE system, respectively, $\mathrm{g} / \mathrm{kg}$. In this study, the influence of the EAHE system on the humidity ratio of ventilation air was neglected [20,28,29]. Therefore, $d_{\mathrm{amb}}$ is equal to $d_{\text {outlet. }}$. This means that the EAHE system only decreases the sensible cooling load of building ventilation when the outlet air temperature of the EAHE system is lower or higher than the indoor temperature in the cooling or heating season, respectively. At this time, the sensible cooling or heating load of ventilation air is equal to zero. The values of the above parameters are provided in Section 4. The energy-saving potential of the EAHE-assisted building ventilation system is calculated by Equation (20).

$$
\eta=\frac{Q_{v e n t}-Q_{E A H E}}{Q_{v e n t}}
$$

\section{Simulation Conditions}

In this study, the proposed mathematic models were adopted to simulate the hourly underground soil temperature at different depths and to predict the outlet air temperature of the EAHE system under different design parameters. The hourly and seasonal total precooling and preheating performance of the EAHE system were estimated. The energy-saving potential of the EAHE system for building ventilation was also evaluated to identify its applicability in a hot-summer and cold-winter climate.

A typical one-story house with a size of $200 \mathrm{~m}^{2}$ was used for testing the performance of the EAHE-assisted building ventilation system. According to the ASHRAE standard of "Ventilation for Acceptable Indoor Air Quality" [44], the ventilation rate of this dwelling house was kept at $243 \mathrm{~m}^{3} / \mathrm{h}$. The ventilation fresh air firstly flows into the buried pipe of the EAHE system and eventually enters the indoor space. The influences of key design parameters such as depth, length, and diameter of the buried pipe on the thermal performance of the EAHE system were estimated. The main parameters for case studies are listed in Table 1.

Table 1. Main parameters for simulation [29].

\begin{tabular}{lll}
\hline Parameter & Value & Unit \\
\hline Pipe depth & $0.1-15$ & $\mathrm{~m}$ \\
Pipe length & $30-100$ & $\mathrm{~m}$ \\
Pipe internal diameter & $100-200$ & $\mathrm{~mm}$ \\
Thickness of pipe wall & 2 & $\mathrm{~mm}$ \\
Thermal conductivity of pipe & 0.16 & $\mathrm{~W} /(\mathrm{mK})$ \\
Ventilation rate & 243 & $\mathrm{~m}^{3} / \mathrm{h}$ \\
Density of air & 1.205 & $\mathrm{~kg} / \mathrm{m}^{3}$ \\
Specific heat capacity of air & 1013 & $\mathrm{~J} /(\mathrm{kgK})$ \\
Thermal conductivity of air & 0.02593 & $\mathrm{~W} /(\mathrm{mK})$ \\
Kinematic viscosity of air & $15.06 \times 10^{-6}$ & $\mathrm{~m} 2 / \mathrm{s}$ \\
Pr & 0.703 & - \\
Density of soil & 2050 & $\mathrm{~kg} / \mathrm{m}^{3}$ \\
Specific heat capacity of soil & 1840 & $\mathrm{~J} /(\mathrm{kgK})$ \\
Thermal conductivity of soil & 0.52 & $\mathrm{~W} /(\mathrm{mK})$ \\
Thermal diffusivity of soil & 0.0004963 & $\mathrm{~m}^{2} / \mathrm{h}$ \\
\hline
\end{tabular}


The TMY weather conditions of a representative city in the hot-summer and cold-winter climatic zone are presented in Figure 3. The maximum ambient air temperature is $38.8^{\circ} \mathrm{C}$ which occurs on 31 July. The coldest day is 24 January, and the minimum ambient air temperature is $-3.9{ }^{\circ} \mathrm{C}$. The humidity radio of the representative city ranges from $1.25 \mathrm{~g} / \mathrm{kg}$ to $29.55 \mathrm{~g} / \mathrm{kg}$. The mean annual soil surface temperature $\left(T_{s, \text { mean }}\right)$, amplitude of annual soil surface temperature $\left(A_{s}\right)$, and time of minimum soil surface temperature $\left(t_{0}\right)$ in Equation $(2)$ are $17.3^{\circ} \mathrm{C}, 17.7^{\circ} \mathrm{C}$, and 557 for the representative city, respectively. The periods of the cooling and heating seasons are from 1 June to 30 September and 15 December to 15 March, respectively [45]. Meanwhile, the indoor air condition is set at $25^{\circ} \mathrm{C}$ and $\mathrm{RH} 55 \%$ for the cooling season and $20^{\circ} \mathrm{C}$ and $\mathrm{RH} 50 \%$ for the heating season, respectively. The humidity ratio of the indoor environment is $11.01 \mathrm{~g} / \mathrm{kg}$ in the cooling season and $7.2 \mathrm{~g} / \mathrm{kg}$ in the heating season.

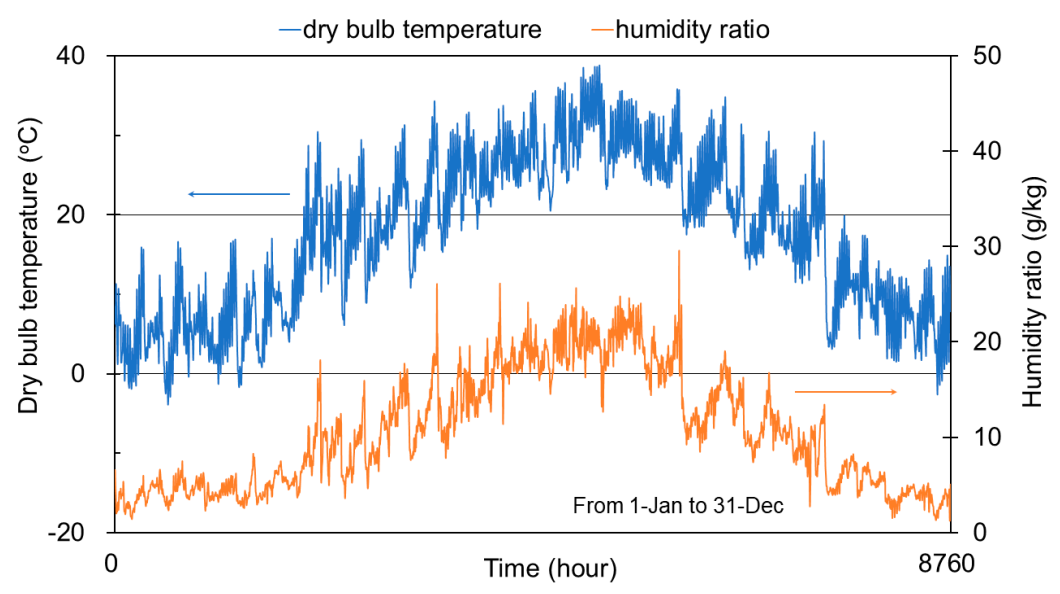

Figure 3. Hourly outdoor weather conditions.

\section{Annual Performance Evaluation and Discussion}

\subsection{Evaluation of Underground Soil Temperature}

The temperature of underground soil determines the precooling and preheating performance of the EAHE system. The variation of ambient weather conditions will show a significant impact on the temperature of underground soil at a shallow depth. When the depth reaches a certain degree, the temperature of underground soil approximately keeps constant with a low fluctuation all year round. In this study, we firstly evaluated the influence of underground depth on the soil temperature to identify the optimal depth of the buried pipe for the EAHE-assisted building ventilation system.

Figure 4 presents the year-round evolution of the underground soil temperature at different depths. The results indicate that the soil temperature follows a fluctuation of the sinusoidal pattern at a shallow underground depth, such as $0.5 \mathrm{~m}$ and $1 \mathrm{~m}$. At an underground depth of $1 \mathrm{~m}$, the soil temperature ranges from $9.7^{\circ} \mathrm{C}$ to $24.9^{\circ} \mathrm{C}$ throughout the whole year, corresponding to a temperature amplitude of $15.2{ }^{\circ} \mathrm{C}$. When the underground depth increases to $5 \mathrm{~m}$, the year-round fluctuation of soil temperature is extremely low with an amplitude of $0.6^{\circ} \mathrm{C}$, and the maximum and minimum soil temperatures are $17.6^{\circ} \mathrm{C}$ and $17.0^{\circ} \mathrm{C}$, respectively. Such a stabilized underground soil temperature can be treated as a low-grade heat source in the heating season and cold source in the cooling season. For an underground depth of $8 \mathrm{~m}$, the temperature of underground soil is approximately constant with an amplitude of less than $0.1^{\circ} \mathrm{C}$.

The year-round temperature amplitudes of underground soil at different depths were calculated to further estimate the stability of underground soil temperature. The calculated results are shown in Figure 5. It can be found that the underground depth shows a significant influence on the stability of soil temperature. When the depth is less than $2 \mathrm{~m}$, the amplitude of underground soil temperature is relatively high which is detrimental to the efficient operation of the EAHE-assisted building ventilation system. This temperature amplitude decreases to practically zero at a depth of $10 \mathrm{~m}$. It means that 
further enlarging the underground depth may be meaningless. Therefore, $5 \mathrm{~m}$ is the optimal depth for this hot-summer and cold-winter climatic condition, considering the compromise between the stability of underground soil temperature and construction costs. In this study, the pipe of the EAHE system was buried at a depth of $5 \mathrm{~m}$.

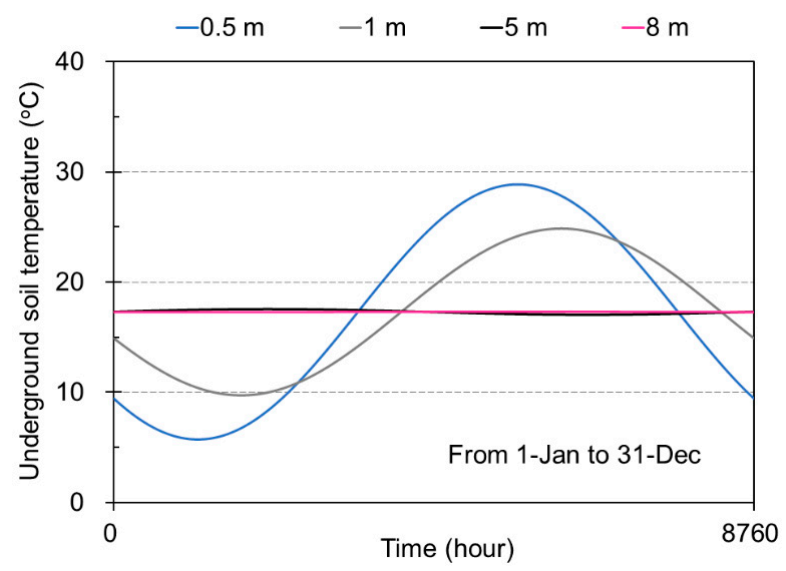

Figure 4. Year-round evolution of the underground soil temperature at different depths.

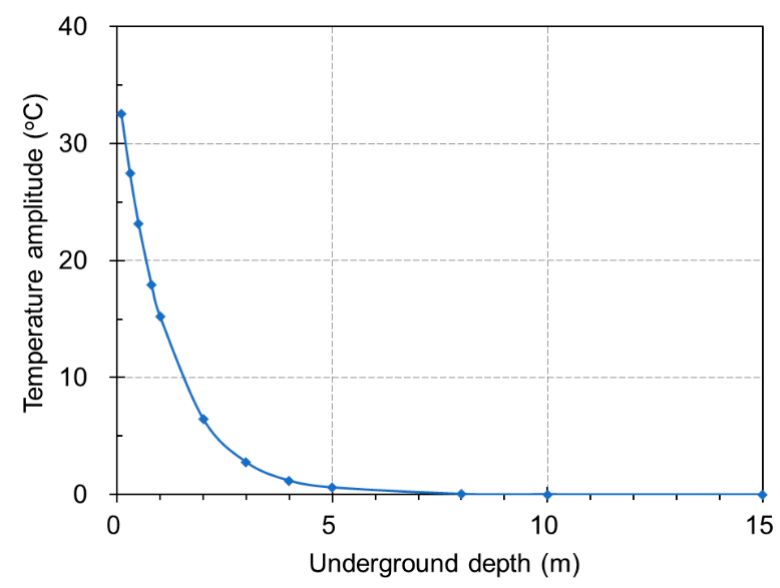

Figure 5. Year-round amplitudes of the underground soil temperature at different depths.

\subsection{Influence of Design Parameters on the Thermal Performance of the EAHE}

In this section, the hourly outlet air temperature of the EAHE system was calculated to estimate the precooling and preheating performance of the EAHE system throughout the whole year. The influences of pipe length and pipe internal diameter on the thermal performance of the EAHE system were investigated. Different pipe lengths ranging from $30 \mathrm{~m}$ to $100 \mathrm{~m}$ were considered. Pipe diameters of $100 \mathrm{~mm}, 150 \mathrm{~mm}$, and $200 \mathrm{~mm}$ were also covered.

Figure 6 presents the influence of pipe length on the hourly outlet air temperature and precooling performance of the EAHE system in the cooling season. The pipe diameter is $150 \mathrm{~mm}$, and the variation is pipe length in the case studies. The results in Figure 6a show that the outlet air temperature of the EAHE system is much lower than the ambient air temperature. A longer pipe length tends to achieve a lower outlet air temperature of the EAHE system. For a pipe length of $30 \mathrm{~m}$, an apparent fluctuation of outlet air temperature can be observed during the whole cooling season. The outlet air temperature ranges from $17.1{ }^{\circ} \mathrm{C}$ to $25.5^{\circ} \mathrm{C}$ according to the variation of the ambient air temperature. This means that the precooling performance of the EAHE system is limited when the pipe length is not long enough. The outlet air temperature can be further reduced and maintain approximately constant 
with a low fluctuation when the pipe length increases from $30 \mathrm{~m}$ to $80 \mathrm{~m}$. Moreover, further reduction of outlet air temperature may be limited in the cooling season by adopting a pipe length of $100 \mathrm{~m}$. The hourly precooling performance of the EAHE system under different pipe lengths in the whole cooling season is shown in Figure $6 \mathrm{~b}$. The precooling performance means the temperature difference between the outlet air of the EAHE and ambient air. The maximum precooling performance of the EAHE system is $13.3{ }^{\circ} \mathrm{C}, 17.2^{\circ} \mathrm{C}, 19.9^{\circ} \mathrm{C}$, and $20.7^{\circ} \mathrm{C}$ for the pipe length of $30 \mathrm{~m}, 50 \mathrm{~m}, 80 \mathrm{~m}$, and 100 $\mathrm{m}$, respectively. The seasonal average precooling performance and average daily cooling capacity of the EAHE system are listed in Table 2. The average precooling performance ranges from $6.2{ }^{\circ} \mathrm{C}$ to $9.6^{\circ} \mathrm{C}$ when the pipe length increase from $30 \mathrm{~m}$ to $100 \mathrm{~m}$. Moreover, the EAHE system with a pipe length of $30 \mathrm{~m}$ can provide a daily cooling capacity of $12.4 \mathrm{kWh}$. When this length increases to $80 \mathrm{~m}$ and $100 \mathrm{~m}$, this value enlarges to $18.6 \mathrm{kWh}$ and $19.4 \mathrm{kWh}$, corresponding to an improvement of $50.2 \%$ and $56.3 \%$, respectively.
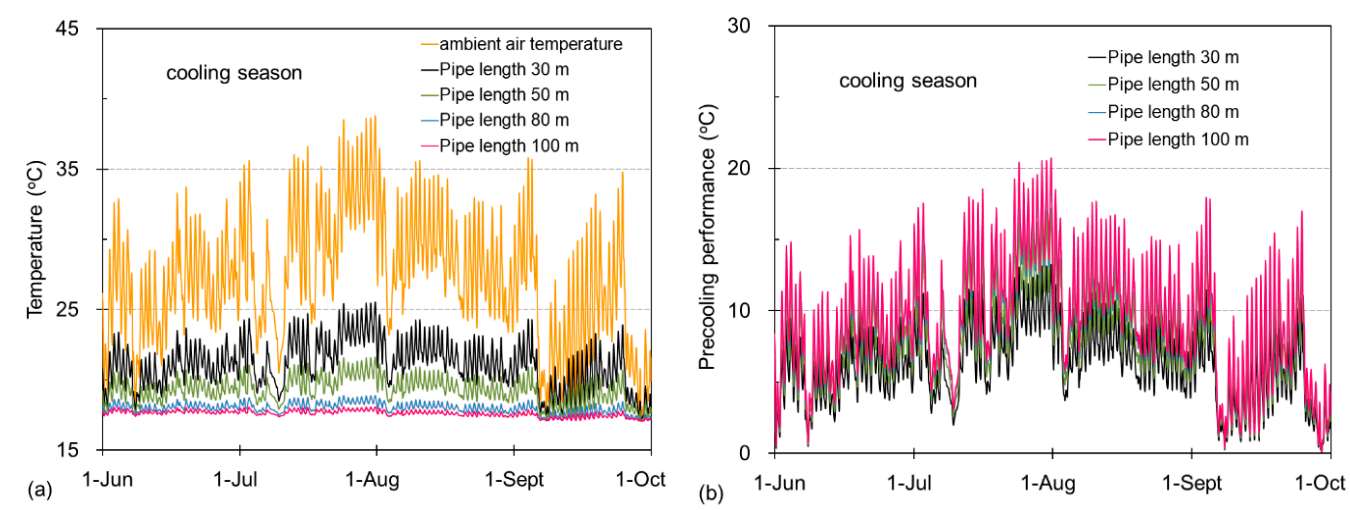

Figure 6. Influence of pipe length on the performance of the EAHE system in the cooling season: (a) outlet air temperature; (b) precooling performance.

Table 2. Seasonal average precooling and preheating performance of the EAHE system under different pipe lengths.

\begin{tabular}{lcccc}
\hline Evaluation Index & $\mathbf{3 0 ~} \mathbf{~}$ & $\mathbf{5 0 ~} \mathbf{~}$ & $\mathbf{8 0 ~} \mathbf{~}$ & $\mathbf{1 0 0} \mathbf{~ m}$ \\
\hline Average precooling performance $\left({ }^{\circ} \mathrm{C}\right)$ & 6.2 & 8.0 & 9.3 & 9.6 \\
Daily cooling capacity $(\mathrm{kWh})$ & 12.4 & 16.1 & 18.6 & 19.4 \\
Average preheating performance $\left({ }^{\circ} \mathrm{C}\right)$ & 7.3 & 9.4 & 10.9 & 11.3 \\
Daily heating capacity $(\mathrm{kWh})$ & 14.6 & 18.9 & 21.9 & 22.8 \\
\hline
\end{tabular}

The influence of pipe length on the thermal performance of the EAHE system in the heating season is illustrated in Figure 7. Similar to the results in the cooling season, the outlet air temperature of the EAHE system is much higher than the ambient air temperature because the ventilation air within the buried pipe can absorb heat from the surrounding soil. A longer pipe length can lead to a higher outlet air temperature in the heating season. For the pipe lengths of $80 \mathrm{~m}$ and $100 \mathrm{~m}$, the outlet air temperature of the EAHE system keeps approximately constant in the whole heating season despite the strong fluctuation of the ambient air temperature. The outlet air temperature of the EAHE system at a pipe length of $100 \mathrm{~m}$ is slightly lower than that of the EAHE with a pipe length of $80 \mathrm{~m}$. The maximum preheating performance is $13.1^{\circ} \mathrm{C}, 16.9^{\circ} \mathrm{C}, 19.6^{\circ} \mathrm{C}$, and $20.4{ }^{\circ} \mathrm{C}$ for the pipe length of $30 \mathrm{~m}, 50 \mathrm{~m}, 80 \mathrm{~m}$, and $100 \mathrm{~m}$, respectively. Moreover, the average preheating performance of the EAHE system is higher than its average precooling performance, as shown in Table 2. This may be because the temperature difference between underground soil and ambient air in the heating season is higher than that in the cooling season. For a pipe length of $30 \mathrm{~m}, 50 \mathrm{~m}, 80 \mathrm{~m}$, and $100 \mathrm{~m}$, a daily average heating capacity of $14.6 \mathrm{kWh}, 18.9 \mathrm{kWh}, 21.9 \mathrm{kWh}$, and $22.8 \mathrm{kWh}$ can be achieved by utilizing the EAHE system to preheat ventilation air. 

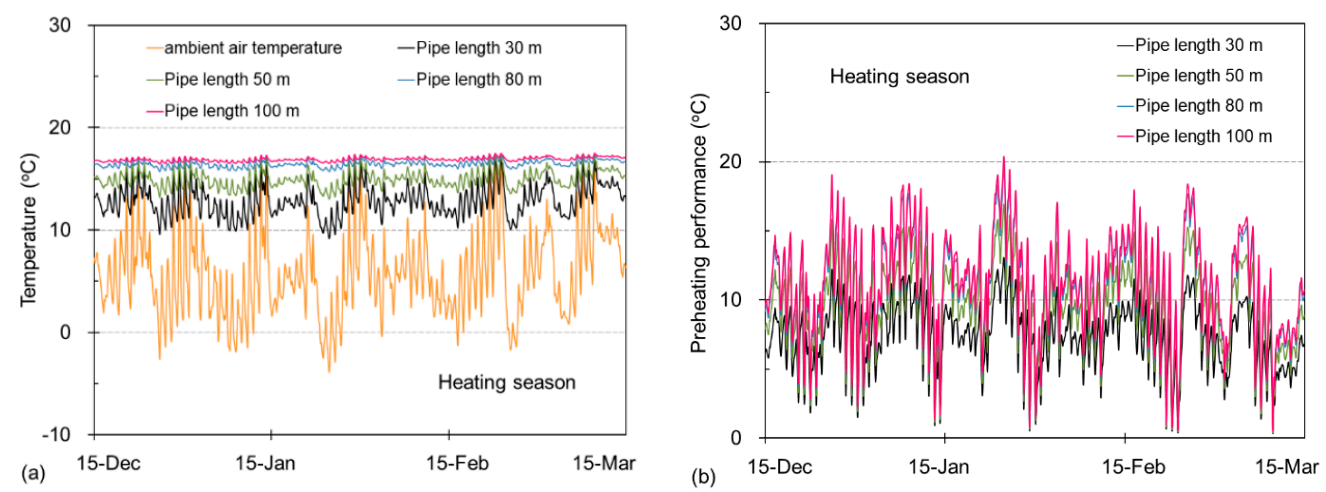

Figure 7. Influence of pipe length on the performance of the EAHE system in the heating season: (a) outlet air temperature; (b) preheating performance.

Based on the above results, it seems that a pipe length of $80 \mathrm{~m}$ is desirable to achieve a promising precooling and preheating performance for the EAHE-assisted building ventilation system throughout the whole year. Considering the compromise between thermal performance and construction costs of the EAHE system, further increase of pipe length may be unhelpful.

Figures 8 and 9 show the influence of pipe internal diameter on the precooling and preheating performance of the EAHE system. To quantitatively identify the influence of pipe diameter, the pipe length is set at $80 \mathrm{~m}$. In this study, the pipe diameter ranges from $100 \mathrm{~mm}$ to $200 \mathrm{~mm}$, corresponding to a variation of the airflow rate within the buried pipe from $8.60 \mathrm{~m} / \mathrm{s}$ to $2.14 \mathrm{~m} / \mathrm{s}$. The results in Figures 8 and 9 suggest that enlarging the pipe diameter will slighter increase the outlet air temperature in summer and decrease this temperature in winter, but its impact is limited. When the pipe diameter increases from $100 \mathrm{~mm}$ to $200 \mathrm{~mm}$, as shown in Table 3, the average precooling performance and daily cooling capacity just varies from $9.4^{\circ} \mathrm{C}$ to $9.1^{\circ} \mathrm{C}$ and $20.2 \mathrm{kWh}$ to $19.6 \mathrm{kWh}$, respectively. Similar results can be observed in the heating season. As the airflow rate within the buried pipe varies from $2.14 \mathrm{~m} / \mathrm{s}$ to $8.6 \mathrm{~m} / \mathrm{s}$, the Nusselt number of ventilation air in the buried pipe increases from 67.7 to 115.6 , and then the convective heat transfer coefficient between ventilation airflow and the pipe wall enhances from $8.77 \mathrm{~W} /\left(\mathrm{m}^{2} \mathrm{~K}\right)$ to $29.97 \mathrm{~W} /\left(\mathrm{m}^{2} \mathrm{~K}\right)$. However, the conductive thermal resistance of the underground soil surrounding the pipe plays a dominant role in the total thermal resistance of the EAHE system. This makes the variation of the convective heat transfer coefficient show a limited impact on the total thermal resistance of the EAHE system. As a result, the outlet air temperature of the EAHE system shows a week connection with the internal diameter of the buried pipe. It should be noted that too large airflow velocity will increase the pressure loss of the pipe. Therefore, an appropriate airflow velocity from $2 \mathrm{~m} / \mathrm{s}$ to $4 \mathrm{~m} / \mathrm{s}$ is recommended.
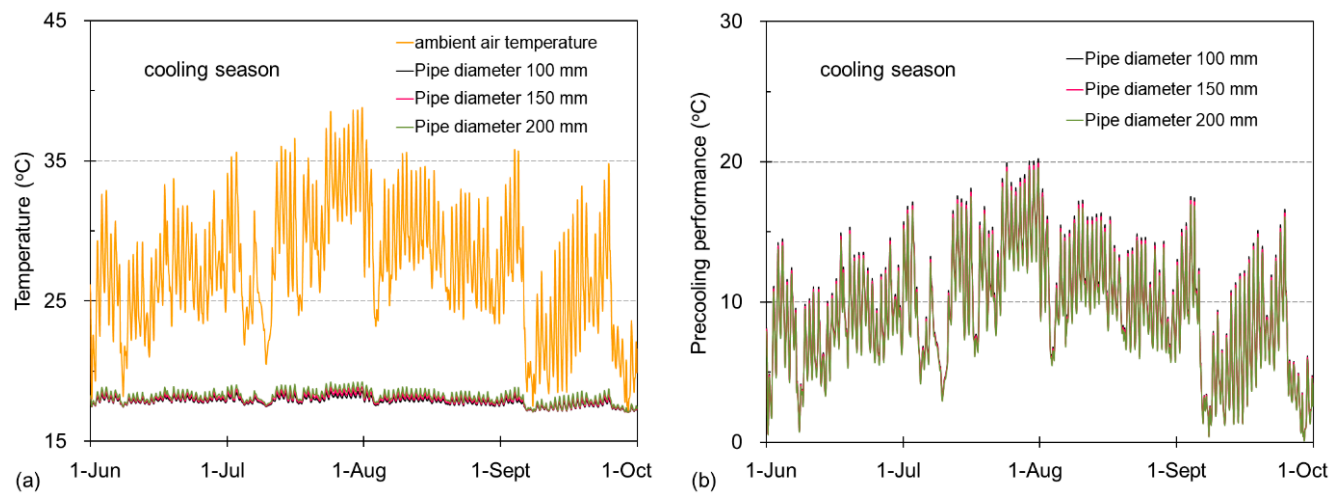

Figure 8. Influence of pipe diameter on the performance of the EAHE system in the cooling season: (a) outlet air temperature; (b) precooling performance. 

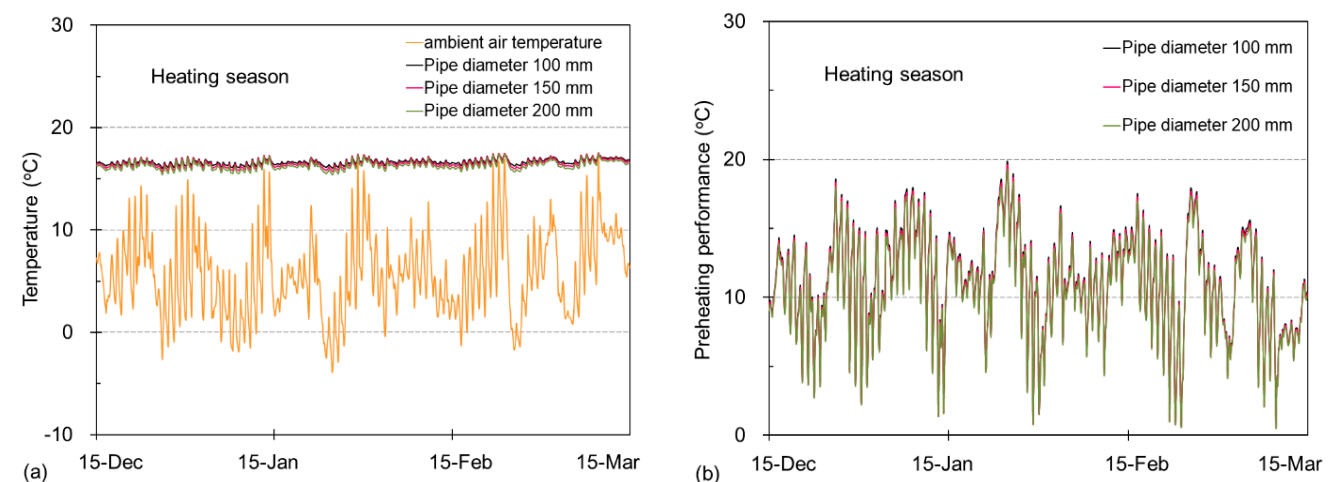

Figure 9. Influence of pipe diameter on the performance of the EAHE system in the heating season: (a) outlet air temperature; (b) preheating performance.

Table 3. Seasonal average precooling and preheating performance of the EAHE system under different pipe diameters.

\begin{tabular}{lccc}
\hline Evaluation Index & $\mathbf{1 0 0} \mathbf{~ m m}$ & $\mathbf{1 5 0} \mathbf{~ m m}$ & $\mathbf{2 0 0} \mathbf{~ m m}$ \\
\hline Average precooling performance $\left({ }^{\circ} \mathrm{C}\right)$ & 9.4 & 9.3 & 9.1 \\
Daily cooling capacity $(\mathrm{kWh})$ & 20.2 & 19.9 & 19.6 \\
Average preheating performance $\left({ }^{\circ} \mathrm{C}\right)$ & 11.0 & 10.9 & 10.7 \\
Daily heating capacity $(\mathrm{kWh})$ & 19.9 & 19.6 & 19.3 \\
\hline
\end{tabular}

\subsection{Energy-Saving Potential of EAHE-Assisted Building Ventilation}

According to Equations (18) and (19), the hourly energy demands for conditioning ventilation air with and without the EAHE system were calculated. The monthly accumulated energy demand for building ventilation was estimated and is presented in Figures 10 and 11. The reduction of energy demand means the relative energy-saving potential by utilizing the EAHE system to precool and preheat ventilation air. The results in Figure 10 show that the EAHE-assisted building ventilation system achieves a reduction of cooling demand ranging from $11.8 \%$ to $19.3 \%$. The humidity ratio of the outdoor environment is relatively high for the selective representative city in summer. This makes the latent cooling load account for a large portion of the total cooling load for building ventilation. For the entire cooling season, as shown in Table 4, the reduction ratio of total energy demand is $16.0 \%$ for the EAHE-assisted building ventilation system.

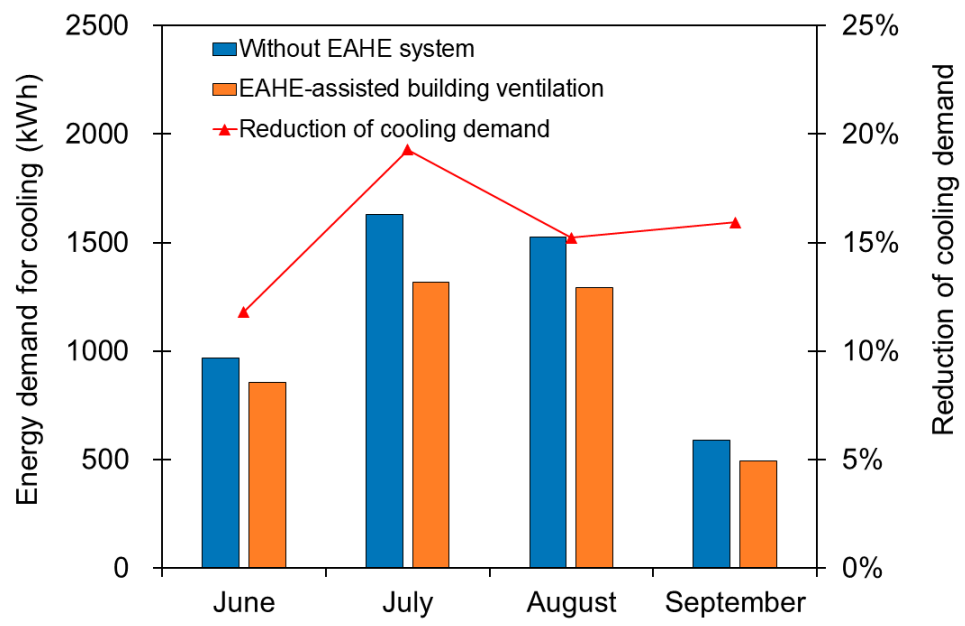

Figure 10. Monthly energy demand for cooling ventilation air with and without the EAHE system. 


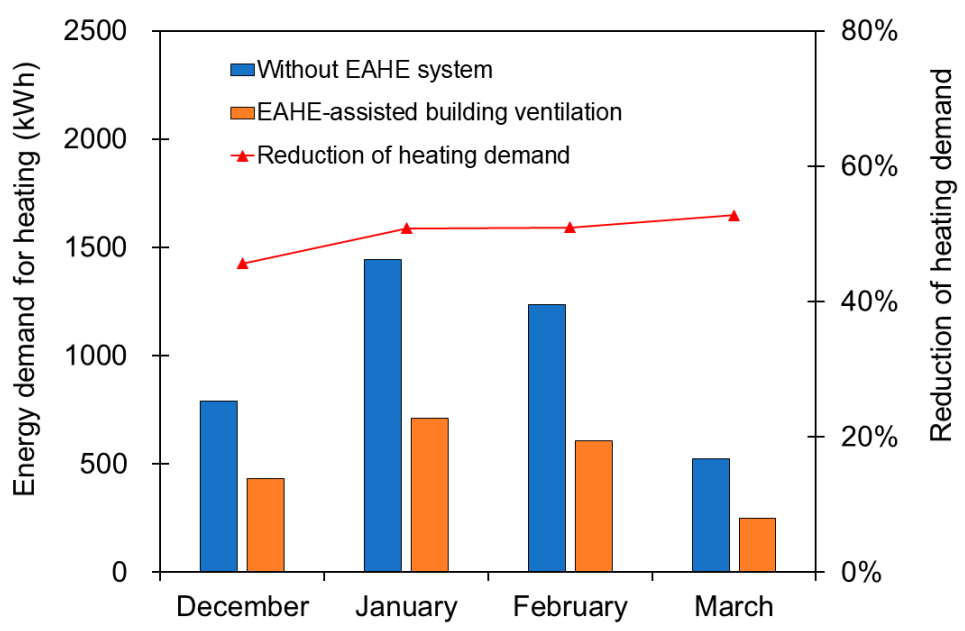

Figure 11. Monthly energy demand for heating ventilation air with and without the EAHE system.

Table 4. Seasonal accumulated energy demand for cooling and heating ventilation air.

\begin{tabular}{cccc}
\hline Accumulated Energy Demand & Ventilation without EAHE System & EAHE-System-Assisted Ventilation & Relative Energy Reduction of EAHE \\
\hline Energy demand for cooling $(\mathrm{kWh})$ & 4711.8 & 3957.2 & $16.0 \%$ \\
Energy demand for heating $(\mathrm{kWh})$ & 3993.5 & 1992.9 & $50.1 \%$ \\
\hline
\end{tabular}

For the heating season, as shown in Figure 11, the EAHE system shows promising potential for reducing the energy demand of building ventilation. The energy demand for building ventilation is $791.1 \mathrm{kWh}, 1443.1 \mathrm{kWh}, 1234.5 \mathrm{kWh}$, and $524.8 \mathrm{kWh}$ in December, January, February, and March, respectively. This monthly energy demand can decrease to $430.2 \mathrm{kWh}, 709.6 \mathrm{kWh}, 605.3 \mathrm{kWh}$, and $247.9 \mathrm{kWh}$ by adopting the EAHE system to preheat ventilation air. The reduction ratio of monthly total energy demand ranges from $45.6 \%$ to $52.8 \%$. For the seasonal total heating demand, a reduction of $50.1 \%$ can be achieved for the EAHE-assisted building ventilation system. Such a year-round energy-saving potential is mainly due to the underground soil temperature approximately keeping constant throughout the whole year. It means the ventilation air within the buried pipe can release heat in summer and absorb heat in winter. Therefore, it can be concluded that the utilization of the EAHE system can effectively precool and preheat ventilation air in summer and winter, respectively, and achieve a promising energy-saving potential for building ventilation.

\subsection{Opportunities of the EAHE System for Net-Zero Energy Buildings}

In recent years, research and development of net-zero energy buildings (NZEBs) are becoming one of the major issues of concern to researchers worldwide because of its energy efficiency, low carbon emission, and sustainability. To achieve the goal of NZEBs, the used primary energy on annual basis should be almost generated by on-site renewable energy [46-48]. Approaches to achieving NZEBs are mainly classified into the following categories: employing renewable energy to meet the energy demand of buildings and reducing the energy demand of buildings [49]. The above results demonstrate that integrating the EAHE system into NZEBs can help to significantly reduce the energy demand for building ventilation. Moreover, the low-grade outlet air of the EAHE system, driven by a solar chimney, can be used to cool down the photovoltaic modules for improving its efficiency of power generation [50]. Furthermore, the airflow window and ventilated wall [51-53] show excellent thermal performance by utilizing low-grade exhaust air to prevent the heat transfer through the window and wall. Integrating the EAHE system with these thermally activated building envelopes will further eliminate the influence of outdoor thermal disturbance on the indoor built environment. Further investigations on the applications of the EAHE system in NZEBs are deserved. 


\section{Conclusions}

The EAHE system can utilize the low-grade thermal energy of underground soil to preheat and precool the flowing air within the buried pipe in the heating and cooling seasons, respectively. To reduce the energy demand of building ventilation, an EAHE-assisted building ventilation system was described and investigated in this study. An analytical model of the underground soil temperature was developed to calculate the hourly evolution of the underground soil temperature at different depths. A steady-state heat transfer model was proposed to simulate the outlet air temperature of the EAHE system and identify its ability to preheat and precool ventilation air. Sensitivity studies were carried out to evaluate the influence of different design parameters on the thermal performance of the EAHE-assisted building ventilation system. The year-round energy-saving potential and design guidelines of the EAHE-assisted building ventilation system were estimated and summarized for the hot-summer and cold-winter climate. The main results are concluded as follows.

At an underground depth of $5 \mathrm{~m}$, the temperature of underground soil is approximately constant throughout the whole year with an amplitude of less than $0.6{ }^{\circ} \mathrm{C}$. A longer pipe length can achieve a larger temperature difference between the outlet air of the EAHE system and ambient air. For the pipe length longer than $80 \mathrm{~m}$, the outlet air temperature of the EAHE system keeps approximately constant throughout the whole year despite the strong fluctuation of the ambient air temperature. Moreover, the internal diameter of the buried pipe shows a limited impact on the thermal performance of the EAHE system. Therefore, a depth of $5 \mathrm{~m}$ and a length of $80 \mathrm{~m}$ are recommended considering the compromise between thermal performance and construction costs of the EAHE system.

The maximum preheating and precooling performance of the EAHE system is $20.4^{\circ} \mathrm{C}$ and $20.7^{\circ} \mathrm{C}$, respectively. This means that the peak cooling and heating loads of buildings can be significantly reduced. Moreover, the EAHE-assisted building ventilation system can reduce by $16.0 \%$ and $50.1 \%$ the energy demand for cooling and heating ventilation air throughout the whole year. Based on the above discussion, it can be concluded that the utilization of the EAHE system can provide an alternative approach to effectively precool/preheat ventilation air and achieve a promising energy-saving potential for building ventilation in the hot-summer and cold-winter climate.

It should be noted that the application of the EAHE-assisted building ventilation system in the heating season performs much better than that in the cooling season. It mainly results from the fact that the EAHE system only helps to reduce the sensible cooling and heating loads of building ventilation. This means that dry climates may be very suitable for the EAHE-assisted building ventilation system, and the energy-saving potential of this system may be limited for the humid climates. Therefore, in our future work, the energy-saving potential and applicability of the EAHE-assisted building ventilation system in different climate conditions will be investigated. Moreover, experimental investigations are needed to validate the mathematic models and provide the actual operation data of the EAHE system in our future studies.

Author Contributions: Conceptualization, C.Z. and W.G.; methodology, C.Z. and W.G.; formal analysis, C.Z.; investigation, C.Z.; resources, F.W. and J.W.; data curation, L.L.; writing-original draft preparation, C.Z.; writing-review and editing, F.W. and W.G.; visualization, C.Z.; supervision, J.W.; project administration, C.Z.; funding acquisition, C.Z. All authors have read and agreed to the published version of the manuscript.

Funding: This research was funded by the National Natural Science Foundation of China (grant number 51808239) and by Hong Kong Scholars Program (grant number XJ2019044).

Conflicts of Interest: The authors declare no conflict of interest.

\section{Nomenclature}

$A_{S} \quad$ amplitude of annual soil surface temperature, $\mathrm{K}$

$C_{a} \quad$ specific heat capacity of air, $\mathrm{kJ} /(\mathrm{kgK})$

d humidity ratio, $\mathrm{g} / \mathrm{kg}$

$e \quad$ thickness of pipe wall, $\mathrm{m}$

EAHE earth-to-air heat exchanger 


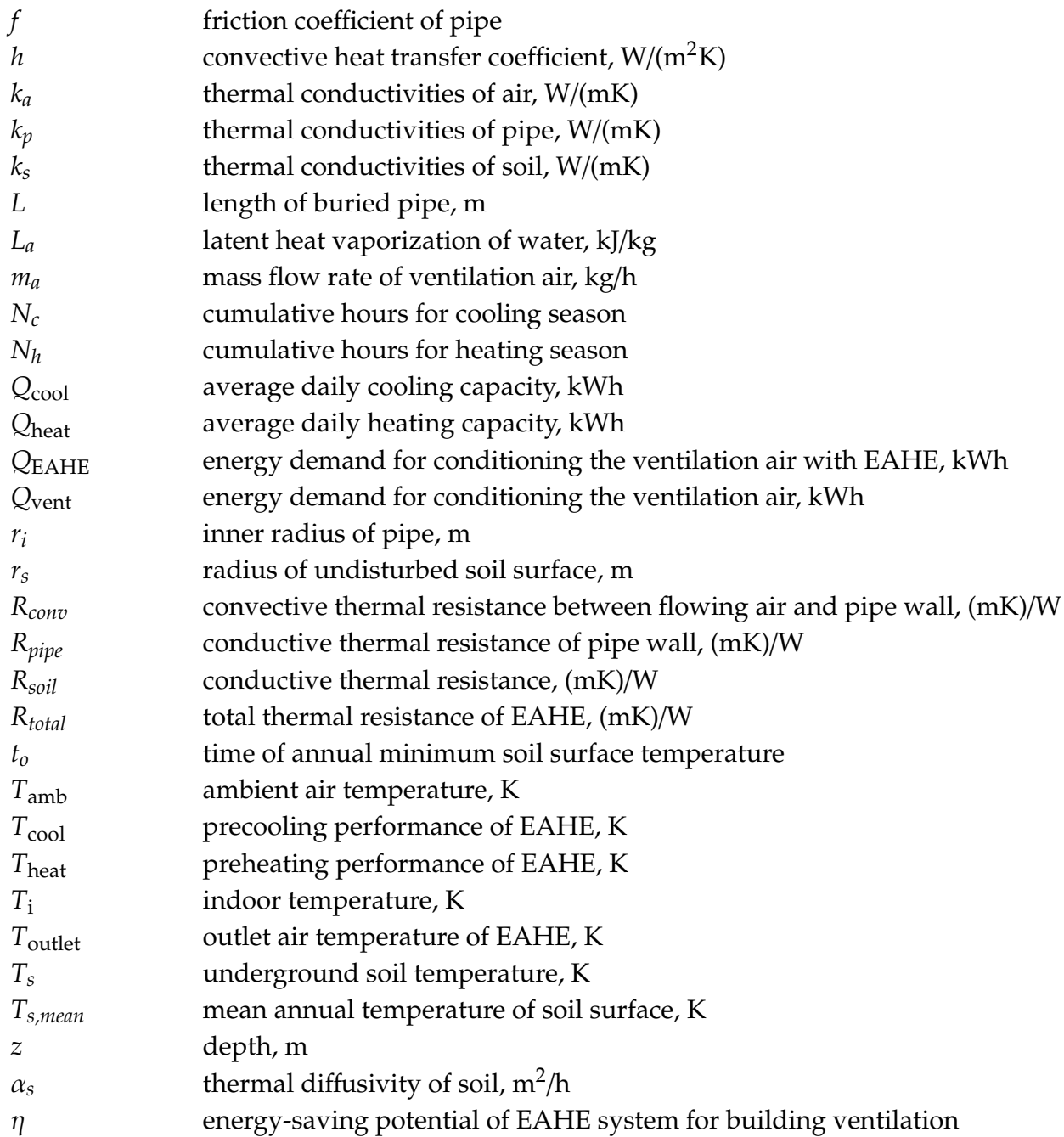

\section{References}

1. Tsinghua University Building Energy Research Center. Annual Report on China Building Energy Efficiency; China Architecture \& Building Press: Beijing, China, 2019.

2. International Energy Agency (IEA). World Energy Statistics and Balances; OECD/IEA: Paris, France, 2018.

3. Ahmed, W.; Asif, M.; Alrashed, F. Application of building performance simulation to design energy-efficient homes: Case study from Saudi Arabia. Sustainability 2019, 11, 6048. [CrossRef]

4. Shahsavar, A.; Khanmohammadi, S. Feasibility of a hybrid BIPV/T and thermal wheel system for exhaust air heat recovery: Energy and exergy assessment and multi-objective optimization. Appl. Eng. 2019, 146, 104-122. [CrossRef]

5. Zhang, C.; Gang, W.J.; Wang, J.B.; Xu, X.H.; Du, Q.Z. Numerical and experimental study on the thermal performance improvement of a triple glazed window by utilizing low-grade exhaust air. Energy 2019, 167, 1132-1143. [CrossRef]

6. Wang, J.B.; Du, Q.Z.; Zhang, C.; Xu, X.H.; Gang, W.J. Mechanism and preliminary performance analysis of exhaust air insulation for building envelope wall. Energy Build. 2018, 173, 516-529. [CrossRef]

7. Fan, C.; Wang, J.; Gang, W.J.; Li, S. Assessment of deep recurrent neural network-based strategies for short-term building energy predictions. Appl. Energy 2019, 236, 700-710. [CrossRef]

8. Zhang, C.; Cui, C.L.; Zhang, Y.; Yuan, J.Q.; Luo, Y.M.; Gang, W.J. A review of renewable energy assessment methods in green building and green neighborhood rating systems. Energy Build. 2019, 195, 68-81. [CrossRef]

9. Tejero-González, A.; Esquivias, P.M. Personalized evaporative cooler to reduce energy consumption and improve thermal comfort in free-running spaces. Sustainability 2019, 11, 6451. [CrossRef] 
10. Yuan, J.Q.; Cui, C.L.; Xiao, Z.W.; Zhang, C.; Gang, W.J. Performance analysis of thermal energy storage in distributed energy system under different load profiles. Energy Convers. Manag. 2020, 208, 112596. [CrossRef]

11. Wiriyasart, S.; Naphon, P. Numerical study on air ventilation in the workshop room with multiple heat sources. Case Stud. Eng. 2019, 13, 100405. [CrossRef]

12. Ribé, O.; Ruiz, R.; Quera, M.; Cadafalch, J. Analysis of the sensible and total ventilation energy recovery potential in different climate conditions. Application to the Spanish case. Appl. Eng. 2019, 149, 854-861. [CrossRef]

13. Albdoor, A.K.; Ma, Z.J.; Cooper, P.; Ren, H.; Al-Ghazzawi, F. Thermodynamic analysis and design optimisation of a cross flow air to air membrane enthalpy exchanger. Energy 2020, 202, 117691. [CrossRef]

14. Wang, L.; Xiao, F.; Niu, X.F.; Gao, D.C. A dynamic dehumidifier model for simulations and control of liquid desiccant hybrid air conditioning systems. Energy Build. 2017, 140, 418-429. [CrossRef]

15. Gurubalan, A.; Maiya, M.P.; Geoghegan, P.J. A comprehensive review of liquid desiccant air conditioning system. Appl. Energy 2019, 254, 113673. [CrossRef]

16. Alongi, A.; Angelotti, A.; Mazzarella, L. Experimental validation of a steady periodic analytical model for breathing walls. Build. Environ. 2020, 168, 106509. [CrossRef]

17. Michaux, G.; Greffet, R.; Salagnac, P.; Ridoret, J.B. Modelling of an airflow window and numerical investigation of its thermal performances by comparison to conventional double and triple-glazed windows. Appl. Energy 2019, 242, 27-45. [CrossRef]

18. Tewari, P.; Mathur, S.; Mathur, J.; Kumar, S.; Loftness, V. Field study on indoor thermal comfort of office buildings using evaporative cooling in the composite climate of India. Energy Build. 2019, 199, 145-163. [CrossRef]

19. Shahsavar, A.; Rajabi, Y. Exergoeconomic and enviroeconomic study of an air based building integrated photovoltaic/thermal (BIPV/T) system. Energy 2018, 144, 877-886. [CrossRef]

20. Fazlikhani, F.; Goudarzi, H.; Solgi, E. Numerical analysis of the efficiency of earth to air heat exchange systems in cold and hot-arid climates. Energy Convers. Manag. 2017, 148, 78-89. [CrossRef]

21. Rosti, B.; Omidvar, A.; Monghasemi, N. Optimum position and distribution of insulation layers for exterior walls of a building conditioned by earth-air heat exchanger. Appl. Eng. 2019, 163, 114362. [CrossRef]

22. Maoz, A.S.; Muhammad, N.; Amin, A.; Sohaib, M.; Basit, A.; Ahmad, T. Parametric optimization of earth to air heat exchanger using response surface method. Sustainability 2019, 11, 3186. [CrossRef]

23. Lee, K.H.; Strand, R.K. The cooling and heating potential of an earth tube system in buildings. Energy Build. 2008, 40, 486-494. [CrossRef]

24. Ascione, F.; Bellia, L.; Minichiello, F. Earth-to-air heat exchangers for Italian climates. Renew. Energy 2011, 36, 2177-2188. [CrossRef]

25. Amanowicz, Ł.; Wojtkowiak, J. Approximated flow characteristics of multi-pipe earth-to-air heat exchangers for thermal analysis under variable airflow conditions. Renew. Energy 2020, 158, 585-597. [CrossRef]

26. Minaei, A.; Safikhani, H. A new transient analytical model for heat transfer of earth-to-air heat exchangers. J. Build. Eng. 2020, 33, 101560. [CrossRef]

27. Gomat, L.J.P.; Motoula, S.M.E.; M'Passi-Mabiala, B. An analytical method to evaluate the impact of vertical part of an earth-air heat exchanger on the whole system. Renew. Energy 2020, 162, 1005-1016. [CrossRef]

28. Al-Ajmi, F.; Loveday, D.L.; Hanby, V.I. The cooling potential of earth-air heat exchanger for domestic buildings in a desert climate. Build. Environ. 2006, 41, 235-244. [CrossRef]

29. Belatrache, D.; Bentouba, S.; Bourouis, M. Numerical analysis of earth air heat exchangers at operating conditions in arid climates. Int. J. Hydrog. Energy 2017, 42, 8898-8904. [CrossRef]

30. Wei, H.B.; Yang, D.; Wang, J.; Du, J.H. Field experiments on the cooling capability of earth-to-air heat exchangers in hot and humid climate. Appl. Energy 2020, 276, 115493. [CrossRef]

31. Li, H.; Ni, L.; Liu, G.; Yao, Y. Performance evaluation of Earth to Air Heat Exchange (EAHE) used for indoor ventilation during winter in severe cold regions. Appl. Eng. 2019, 160, 114111. [CrossRef]

32. Li, H.; Ni, L.; Yao, Y.; Sun, C. Experimental investigation on the cooling performance of an Earth to Air Heat Exchanger (EAHE) equipped with an irrigation system to adjust soil moisture. Energy Build. 2019, 196, 280-292. [CrossRef]

33. Li, H.; Ni, L.; Liu, G.; Zhao, Z.; Yao, Y. Feasibility study on applications of an Earth-air Heat Exchanger (EAHE) for preheating fresh air in severe cold regions. Renew. Energy 2019, 133, 1268-1284. [CrossRef] 
34. Kumar, R.; Ramesh, S.; Kaushik, S.C. Performance evaluation and energy conservation potential of earth-air-tunnel system coupled with non-air-conditioned building. Build. Environ. 2003, 38, 807-813. [CrossRef]

35. Xamán, J.; Hernández-López, I.; Alvarado-Juárez, R.; Hernández-Pérez, I.; Álvarez, G.; Chávez, Y. Pseudo transient numerical study of an earth-to-air heat exchanger for different climates of México. Energy Build. 2015, 99, 273-283. [CrossRef]

36. Liu, Z.; Yu, Z.J.; Yang, T.; Roccamena, L.; Sun, P.; Li, S.; Zhang., G.; El Mankibi, M. Numerical modeling and parametric study of a vertical earth-to-air heat exchanger system. Energy 2019, 172, 220-231. [CrossRef]

37. Ghosal, M.K.; Tiwari, G.N. Modeling and parametric studies for thermal performance of an earth to air heat exchanger integrated with a greenhouse. Energy Convers. Manag. 2006, 47, 1779-1798. [CrossRef]

38. Al-Ajmi, F.; Hanby, V.I.; Loveday, D.L. Thermal performance of the subsoil environment in a dry desert climate. ASHRAE Trans. 2002, 108, 395-405.

39. Derbel, H.B.J.; Kanoun, O. Investigation of the ground thermal potential in Tunisia focused towards heating and cooling applications. Appl. Eng. 2010, 30, 1091-1100.

40. Maerefat, M.; Haghighi, A.P. Passive cooling of buildings by using integrated earth to air heat exchanger and solar chimney. Renew. Energy 2010, 35, 2316-2324. [CrossRef]

41. Bansal, V.; Mishra, R.; Agarwal, G.D.; Mathur, J. Performance analysis of integrated earth-air-tunnel-evaporative cooling system in hot and dry climate. Energy Build. 2012, 47, 525-532. [CrossRef]

42. Gnielinski, V. New equation for heat and mass transfer in turbulent pipe and channel flow. Int. Chem. Eng. 1976, 16, 359-368.

43. Zhong, K.; Kang, Y. Applicability of air-to-air heat recovery ventilators in China. Appl. Eng. 2009, 29, 830-840. [CrossRef]

44. ASHARE. Standard. In Ventilation for Acceptable Indoor Air Quality; American Society of Heating, Refrigerating and Air Conditioning Engineering, Inc.: Atlanta, GA, USA, 2013.

45. Ministry Housing and Urban-Rural Development of People's Republic of China. Design Standard for Energy Efficiency of Residential Buildings in Hot Summer and Cold Winter Zone (JGJ134-2010); Architecture \& Building Press: Beijing, China, 2010.

46. Sudhakar, K.; Winderl, M.; Priya, S.S. Net-zero building designs in hot and humid climates: A state-of-art. Case Stud. Eng. 2019, 13, 100400. [CrossRef]

47. Piderit, M.B.; Vivanco, F.; van Moeseke, G.; Attia, S. Net Zero Buildings-A Framework for an Integrated Policy in Chile. Sustainability 2019, 11, 1494. [CrossRef]

48. Piasecki, M.; Fedorczak-Cisak, M.; Furtak, M.; Biskupski, J. Experimental confirmation of the reliability of fanger's thermal comfort model—Case study of a near-zero energy building (NZEB) office building. Sustainability 2019, 11, 2461. [CrossRef]

49. Ascione, F.; D'Agostino, D.; Marino, C.; Minichiello, F. Earth-to-air heat exchanger for NZEB in Mediterranean climate. Renew. Energy 2016, 99, 553-563. [CrossRef]

50. Sajjad, U.; Amer, M.; Ali, H.M.; Dahiya, A.; Abbas, N. Cost effective cooling of photovoltaic modules to improve efficiency. Case Stud. Eng. 2019, 14, 100420. [CrossRef]

51. Zhang, C.; Gang, W.J.; Xu, X.H.; Li, L.; Wang, J.B. Modelling, experimental test, and design of an active air permeable wall by utilizing the low-grade exhaust air. Appl. Energy 2019, 240, 730-743. [CrossRef]

52. Zhang, C.; Gang, W.J.; Wang, J.B.; Xu, X.H.; Du, Q.Z. Experimental investigation and dynamic modeling of a triple-glazed exhaust air window with built-in venetian blinds in the cooling season. Appl. Eng. 2018, 140, 73-85. [CrossRef]

53. Zhang, C.; Wang, J.B.; Li, L.; Gang, W.J. Dynamic thermal performance and parametric analysis of a heat recovery building envelope based on air-permeable porous materials. Energy 2019, 189, 116361. [CrossRef]

(C) 2020 by the authors. Licensee MDPI, Basel, Switzerland. This article is an open access article distributed under the terms and conditions of the Creative Commons Attribution (CC BY) license (http://creativecommons.org/licenses/by/4.0/). 